\title{
Elaboration of technology organizational models of constructing high-rise buildings in plans of construction organization
}

\author{
Irina Osipenkova ${ }^{1}$, Tatyana Simankina ${ }^{2 *}$, Taisiia Syrygina ${ }^{3}$, and Vitaliy Lukinov ${ }^{4}$ \\ ${ }^{1}$ Saint-Petersburg State University of Architecture and Civil Engineering, 2-nd Krasnoarmeiskaya St., \\ 4, St. Petersburg, 190005, Russia \\ 2, 3 Peter the Great St. Petersburg Polytechnic University, Polytechnicheskaya, 29, St. Petersburg, \\ 195251, Russia \\ ${ }^{4}$ Moscow State University of Civil Engineering, Yaroslavskoe shosse, 26, Moscow, 129337, Russia
}

\begin{abstract}
This article represents features of the elaboration of technology organizational models of high-rise building construction in technology organizational documentation on the example of the plan of construction organization. Some examples of enhancing the effectiveness of high-rise building construction based on developments of several options of the organizational and technological plan are examined. Qualitative technology organizational documentation allows to increase the competitiveness of construction companies and provides prime cost of construction and assembly works reductions. Emphasis is placed on the necessity to comply with the principle of comprehensiveness of engineering, scientific and research works, development activities and scientific and technical support.
\end{abstract}

\section{Introduction}

In recent decades Russian construction companies have accumulated enormous experience of high-rise and top buildings construction. They take into account design characteristics of tall buildings that have a significant impact on technological and organizational solutions of high-rise construction.

This article represents certain aspects of technological and organizational solutions for the design and construction of high-rise buildings of monolithic reinforced concrete. In most cases, both abroad and in Russia load-bearing framework of high-rises are built of monolithic reinforced concrete [1].

The main feature of high-rise construction that affects the technology organizational model of its erection is a concentration of large amounts of monolithic concrete in construction footprint [2]. If in a multi-storey (25-30 floors) building there are 9-11 $\mathrm{m}^{3}$ of reinforced concrete per $\mathrm{m}^{2}$ of construction footprint whereas in high-rise buildings with 100200 floors this parameter reaches $50-60 \mathrm{~m}^{3} / \mathrm{m}^{2}$.

The vertical orientation of a high-altitude house, limited size of floor working area, large amount of floors require minimizing the amount of time wasted on construction of one floor.

\footnotetext{
* Corresponding author: talesim@mail.ru
} 
Besides, significant increases in wind speed and intermittent wind loading mode that occur from an increase in building's size are a very important circumstance that influences the speed if highrises construction.

It follows that in plans of construction organization (PCO) that are a component of project documentation many factors affecting the technology organizational model of constructing high-rises should be envisaged. Most important challenges of PCO include making decisions that allow to provide the possibility to implement a row of effective organizational and technological plans, because PCO is the main document of strategic planning of the construction process which defines policy decisions on technology and organization of production that are detailed in further documents.

\section{Methods}

The elaboration of the technology organizational model of high-rise construction assumes a whole range of effective organizational and technological measures that promote to shorten the timescales and reduce labour intensity input at the same level of quality.

Linkage between the requirements of project/working documentation, production technology, the conditions of construction area, definition of technical feasibility, safety, economy and ecology is undertaken by the method of formulating of a particular technical task and the detailed reasoning on the way to address it that meets the indicated requirements. Organizational and technological plans merged in the settlement pattern are the result of elaboration of technological and organizational solutions.

Technology organizational model links substantiation, methods and rules that apply to the linkage between the requirements of the project documentation, technology and safety of production, specific conditions for construction and the environment during erection of certain object's constructions or its parts in specific conditions.

Technology organizational model is a primary core for establishing the costs of the construction and for its security assessment. This understanding makes it possible to evaluate consolidated design, technological and organizational solutions tailored to high-rise building. In technology organizational schemes it is important to define the most effective construction methods and the sequence of high-rises building choosing appropriate machinery, mechanisms, equipment and devices for the accomplishment of the main types of work [3]. Placing concrete batching plant (portable factory) at a construction site is an example of the effective organizational and technological solution for high-rises building [4]. It's possible to smoothly provide the facility to be constructed with ready-mixed concrete as the transportation of concrete mixture to the place of its preparation does not depend, for example, on heavy traffic.

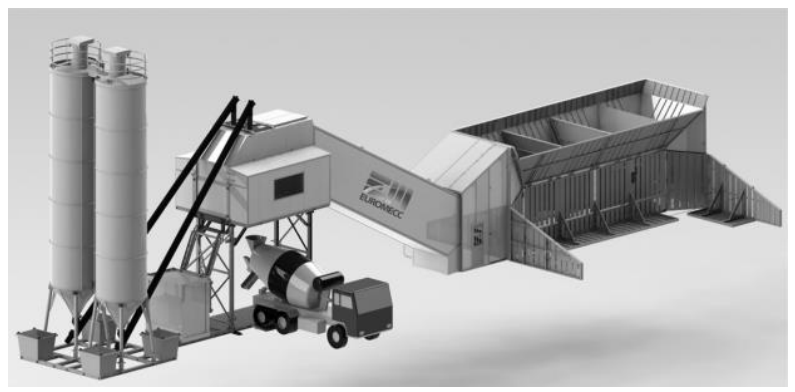

Fig. 1. Portable concrete batching plant

Reloading-free supply of concrete mixture is possible while concreting constructions using 
«crane - hopper» method. In this case concrete mixture goes from a concrete mixer to concreting hoppers installed in the body of a drop-side track which delivers them to the coverage of the assembly crane. With a crane the mixture is delivered to the working horizon and poured into the formwork. Thus, apart from productivity growth, we reach concreting cost reduction as the cost of an auto concrete mixer's machine-shift is 2,5-3 times bigger than the cost of the machine-shift of a drop-side truck. That plan of concreting organization is relevant in concreting of load-bearing structures (columns, cross bars, floor slabs etc.) of the lower floors (for example, from 1 to 20) of high-rise buildings. Justification of the scope of this scheme of concreting is needed in a case-by-case basis.

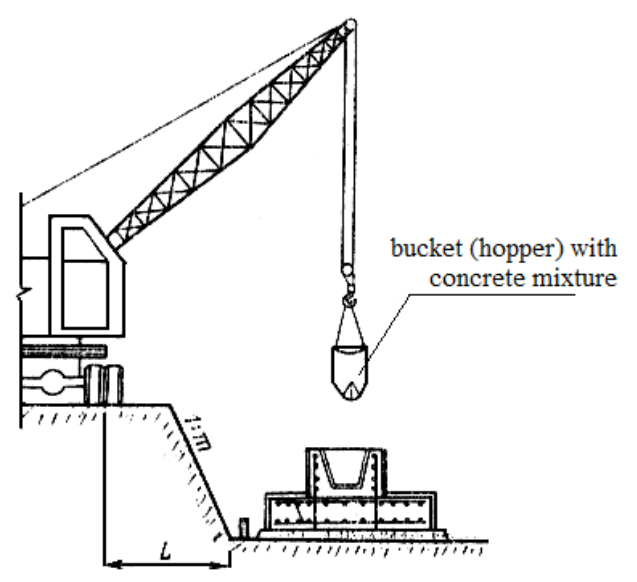

Fig. 2. «Crane - hopper» method in concreting the part of the structure

It is possible to organize transportation of concrete in borders of building site from the mixing plant to the area that needs to be concreted with stationary concrete pumps. That plan of concreting can be relevant in high-rise buildings' monolithic foundation and carcassing.

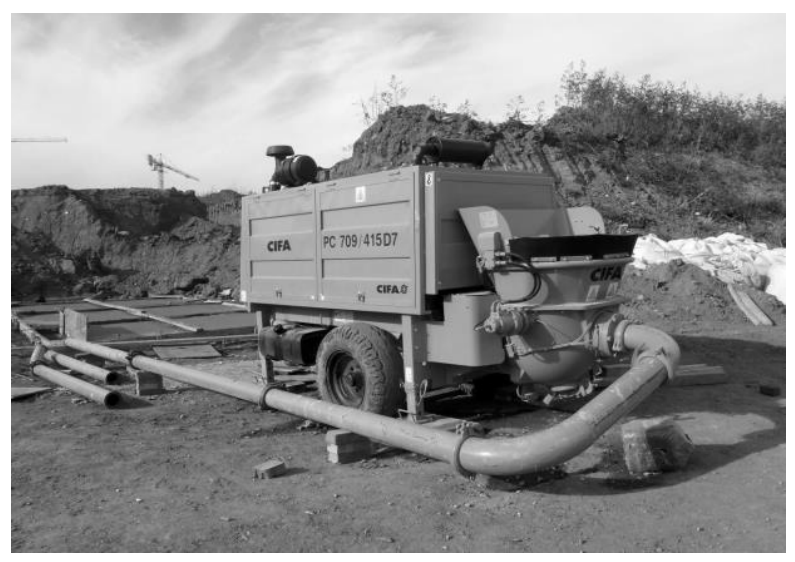

Fig. 3. Stationary concrete pump

Depth of laying a foundation varies from 3-4 to 8-10 m. [1, 5]. In so doing, most of concrete is placed lower than the surface level. In this case concrete pipe of concrete pump placed in the area of batching plant is made of steel links of concrete pump, whereas supplying of concrete mixture to concrete block foundation is accomplished via a flexible concrete pipe. 
While concreting building's upper stories the system for concrete supplying consists of three parts: horizontal - from a batching plant to the placement of vertical concrete pipe; vertical concrete pipe; stationary boom. Depending on technical parameters of used concrete pumping equipment, in junctions of stated parts and throughout its length and (or) heights are set auxiliary stations of concrete pumping [6].

In contrast to linear type facilities that provide during its construction the suitable conditions for simultaneous execution of rebar, formwork activities and concreting in different work zones in borders of one floor, it high-rise building the area of a floor is smaller and the challenge of acceleration of increasing of stripping strength of concrete are pressing. The placement of batching plant near the high-rise building on a construction site creates favorable conditions for intensification of concrete pouring in hardening of concrete.

One of the directions of the accelerating of load-bearing structure building is an expansion of the borders of applicability of the thermos method. A set of rules 70.13330 "Load-carrying and cladding structures" allows the heating of concrete mixtures with Portland cement to $+35^{\circ} \mathrm{C}$ but not more. This temperature restriction of concrete mixture heating in the process of its preparation is due to the requirement of maintaining of concrete workability for a time from its preparation to its pouring. In normal conditions of the massive construction the distance from the factory that supplies custom concrete can reach dozens of kilometers and transport time of concrete mixture - 1,5-2 hours. If a concrete production plant is placed on a construction site then transportation takes 10-20 min.

\section{Results}

The study of the setting time of concrete in increased temperature conditions (provided on [7]) has revealed that, for example, Portland cement M500 starts to set in 1,2 - 1,3 hours even at a temperature of $50^{\circ} \mathrm{C}$. Consequently, with experimental justification load-bearing structures are recommended to pour with mixtures heated to $40-50^{\circ} \mathrm{C}$ at a batching plant and to use hot-thermos method. The hardening time of concrete will be comparable to heating methods with minimized energy consumption and labour input. Moreover, the quality of concrete, prepared of preheated mixture is better that the quality of concrete that is heated, for example, with heating cable. This is because both in the hot-thermos method and in the method of electric preheating of concrete mixture, heat is delivered to concrete mixture before its pouring and setting. It follows that in both these methods destructive phenomena caused by uneven volumetric expansion of concrete mixture components are minimized.

It should be mentioned that the hot-thermos method with its increased temperature of concrete mixture heating that provides shortening of time frames, reduction of energy consumption and labour input, improving the quality of concrete does not apply to the concreting of massive monolithic foundations. Applied to the foundations of high-rises, appears the opposite problem of diminishing the influence of cement's exothermic heat on the concrete's state of tension to avoid cracks. Directions and ways of solving this problem are not examined in this article.

Usage of high-strength sorts of concrete in high-rise construction in the building of a loadbearing framework of overground building's parts are a strong trend. Experience of designing and construction of top buildings indicates that in construction of supporting structures of the same building different classes of concrete(from B120-B100 to B60-B40) are applied basing on the dependency of the pressure on elevation [6].

\section{Conclusion}

Increased strength characteristics of high-performance types of concrete is provided by 
rational choice of its components, including highly-effective modified supplements. Most ready-mixed concrete factories are targeted at the production large deployments concrete, including high-quality (but not high-strength). That is another argument bearing witness to the feasibility of placing a concrete batching plant at a construction site capable of preparing concrete mixtures, taking into account specificities of high-rise building including a row of high-strength sorts of concrete.

In addition, it's impossible to avoid research and development related to implementation of separate project, organizational and technological decisions that reflects the specificity of high-rise construction.

It is also necessary to provide scientific and technical support at all stages of design, construction and exploitation of high-rises [8].

It this article were examined some examples of improving the effectiveness of high-rise construction on the basis of development of several options of technology organizational schemes. Qualitative technology organizational documentation allows to increase the competitiveness of construction companies and to reduce prime cost of construction and assembly works.

\section{References}

1. M.F. Markovskiy, Arkhitektura i stroitel'stvo, 2, 220 (2011)

2. M.A. Romanovich, Increase of technology organizational reliability in cast-in-place construction based on model engineering of time schedule parameters] (PhD Thesis), Saint-Petersburg: SPSUACE (2015)

3. L.M. Kolchedantsev, S.V. Volkov, Zhilishchnoe Stroitelstvo, 11, 21-26 (2015)

4. L.M. Kolchedantsev, I.G. Osipenkova, Zhilishchnoe Stroitelstvo, 11, 17-19 (2013)

5. I.G. Osipenkova, T.L. Simankina, R.R. Nurgalina, Fundamentals of organization and management in construction (Saint-Petersburg, SPSUACE, 2013)

6. M.F. Markovskiy, A.V. Shcherbach, Arkhitektura i stroitel'stvo, 1, 82-89 (2013)

7. L.M. Kolchedantsev, Intensification of concrete works on the base of the thermovibrating processing of concrete mixture ( $\mathrm{PhD}$ Thesis), Saint-Petersburg: SPSUACE (2002)

8. Russian Regional guidance document 31-04-2008 «Recommendations for the construction of residential and public buildings»» 